\title{
Enhancing Financial Inclusion in ASEAN: Identifying the Best Growth Markets for Fintech
}

\author{
Mark Kam Loon Loo
}

Mihalcheon School of Management, Concordia University of Edmonton, Edmonton, AB T5B 4E4, Canada; mark.loo@concordia.ab.ca

Received: 17 November 2019; Accepted: 28 November 2019; Published: 4 December 2019

check for updates

\begin{abstract}
While most of the advanced economies are facing saturated markets, the Association of Southeast Asian Nations (ASEAN) has been touted a stable and attractive investment region averaging 5.4\% growth since 1980. In 2013, ASEAN overtook China as the top foreign direct investment destination. Boasting the world's fifth largest economy with over 650 million people and 400 million reaching middle class, ASEAN has commendably transitioned from a subsistence economy to product and service industries. Despite the success, many live in marginalized areas without access to banking facilities. Advancing internet capability and availability present investors an opportunity to offer financial technology, or Fintech, to meet the need for financial services in this digital era. The aim of this research is to identify the countries with the highest need for financial inclusion and, hence, the best potential for Fintech growth. The results may help governments formulate policy that improves investment competitiveness. The methodology includes identifying relevant criteria and allocating weight to each criterion to evaluate the best international markets. The findings show Vietnam, Laos, and Cambodia as the countries with the highest potential. The associated risks and opportunities are discussed, followed by managerial implications, limitations, and recommendations for future research.
\end{abstract}

Keywords: ASEAN; financial inclusion; Fintech; risk; foreign direct investment; competitiveness

\section{Introduction}

ASEAN stands for the Association of Southeast Asian Nations comprising 10 members: Brunei, Cambodia, Indonesia, Laos, Malaysia, Myanmar, Philippines, Singapore, Thailand, and Vietnam. ASEAN has been outperforming the global growth rate averaging over 5.4\% annual GDP since 1980, and in 2013, its foreign direct investment eclipsed China's. ASEAN has the world's fifth largest economy, third largest population with over 650 million, and a growing middle class reaching 400 million by 2020 . The fast-emerging economies of Cambodia, Laos, Myanmar, and Vietnam average $7 \%$ growth. Business analysts agree that ASEAN is a high-growth region with strong intra-Asian trade, manufacturing supply chains with Northeast Asia, and massive infrastructure expansion over the next two decades. China's One Belt One Road, with three of five corridors across ASEAN connecting to some 60 countries, is expected to enhance ASEAN's competitiveness.

Christine Lagarde (Lagarde 2018), the International Monetary Fund (IMF) Managing Director, noted while ASEAN shows positive growth trends, ASEAN is subject to heightened competition, financial volatility, and technological advances such as digitalization, robotics, and artificial intelligence. ASEAN countries could navigate the difficult terrain by managing uncertainty, making economies more inclusive, and preparing for the digital revolution.

Although ASEAN countries have built stronger economic foundations that helped weather the global financial crisis, recent volatility in financial markets reminds policymakers to stay vigilant to manage uncertainties, and safeguard against volatile capital flows with bold reforms to make economies more resilient. 
Many ASEAN countries have shifted from agriculture to advanced manufacturing and services but new growth models that are more inclusive are needed to sustain growth. ASEAN can work together to promote inclusive growth by increasing the quality of education and infrastructure, eliminating red tape and corruption, providing affordable childcare to encourage more women in workforce, and enhancing women's access to finance. However, all this will only go so far.

A McKinsey and Company (McKinsey and Company 2016) study found that $60 \%$ of current jobs comprise tasks will soon be automated. New growth models will rely on technological innovations from artificial intelligence to robotics, to biotechnology, to fintech or financial technology. Lee and Teoh (2015) argue that Fintech will bring about lower business costs and profit margins. An estimated 38\% of the world population has no formal bank accounts and another $40 \%$ are underserved by banks, providing a huge potential market for Fintech firms.

With mobile payment systems, Fintech has become the new economy. Indonesia has a vibrant digital ecosystem with more than 1700 start-ups and Go-Jek is a transformation example from a ride-hailing app into a platform for mobile payments and other services. The Singapore Fintech Festival gathers some of the world's most dynamic entrepreneurs and innovators.

Fintech is the platform for the digital revolution that promotes financial inclusion. It is not just a boost to productivity, but also one that works for young and old, rich and poor, urban and remote communities to help create a smarter and fairer economy.

In ASEAN, only $50 \%$ of adults have an account at a financial institution and 264 million adults keep money at home and borrow from "loan sharks" at exorbitant interest rates. Rates of financial exclusion are higher among the poor, less-educated, and those living in rural areas. Recognizing the importance of financial inclusion for economic development, ASEAN leaders aim to achieve $70 \%$ account ownership by 2020 (Luna-Martinez 2016).

From the above discussion, there is a critical need to enhance Fintech to help ASEAN people access financial services to receive and save wages safely and build credit history. Which ASEAN countries would offer the greatest growth for financial inclusion to attract Fintech investors?

\section{Objective}

The objective of this research is to identify ASEAN markets that offer the best growth potential for financial inclusion to attract Fintech investors.

There are three associated research questions to guide the research project. What may be some factors that attract Fintech investors? How should markets be evaluated to determine the best potential for financial inclusion? What type of investors may value social returns over immediate profit in growing financial inclusion in ASEAN?

\section{Literature Review}

Financial inclusion is the process that ensures the ease of access, availability, and usage of formal financial system that offers equality of opportunities to access financial services to all members of a nation (Sarma 2008; Nanda and Kaur 2016) and access to a transaction account is a first step toward broader financial inclusion since a transaction account allows people to store money, and send and receive payments (World Bank 2019). This definition implies there is financial exclusion, and the (World Bank 2016) describes voluntary exclusion as a condition where the segment of the population or firms choose not to use financial services either because they have no need or due to cultural or religious reasons.

Involuntary exclusion may arise from an individual's insufficient income or high risk profile, discrimination by race, religion, or gender, market failures, and imperfections. The poor are excluded from wage-earning employment opportunities that traditional economic theory presupposes (Park and Mercado 2015). They live and work in the informal economy, not by choice but by necessity (Cull et al. 2014), managing a broad range of financial services by themselves to sustain livelihoods, build asset, and manage risks. They have limited financial access, which excludes them from the normal financial system. 


\subsection{Does Financial Inclusion Lower Income Inequality?}

Many financial inclusion studies focused on the role of financial access in lowering poverty and income inequality.

A study in India provides empirical evidence that local differences in opening bank branches in rural unbanked population were associated with significant reduction in rural poverty (Burgess and Pande 2005). Cull, Ehrbeck, and Holle (Cull et al. 2014) suggest that financial access improves local economic activity.

Research in Mexico showed that rapid opening of Banco Azteca branches had a significant correlation with the region's economy leading to $7 \%$ increase in overall income levels compared to areas without Banco Azteca branches being opened (Bruhn and Love 2009). Ruiz (2013) explained that households were better able to smooth consumption and accumulate more durable goods in communities with Banco Azteca branches. At the same time, the proportion of households that saved money declined $6.6 \%$ in those communities, suggesting that households were able to rely on savings rather than available formal credit as a buffer against income fluctuation (Cull et al. 2014).

At the macroeconomic level, the literature suggests that the degree of financial intermediation is not only positively correlated with economic growth and employment under normal circumstances, but it is generally believed to casually impact economic growth (Levine 2000; Pasali 2013). The main mechanism for doing so is generally lower transaction costs and better distribution of capital and risk across the economy. Moreover, broader access to bank deposits can also have a positive effect on financial stability (Cull et al. 2014). However, Demetriades and Law (2006) indicated that the positive growth impact from financial intermediation does not hold in economies with weak institutional frameworks and nonexistent financial regulation.

\subsection{Financial Inclusion in ASEAN}

Financial inclusion could be measured in multiple dimensions, including account ownership, use of account, and financial account penetration. Table 1 shows the financial account penetration by percent of total adult population for ASEAN nations.

Table 1. Financial account penetration ( $\%$ of total adult population).

\begin{tabular}{|c|c|c|c|c|c|c|c|c|c|}
\hline Singapore & Malaysia & Thailand & Indonesia & Philippines & Vietnam & Lao PDR & Myanmar & Cambodia & Brunei \\
\hline $98 \%$ & $85 \%$ & $82 \%$ & $49 \%$ & $34 \%$ & $31 \%$ & $29 \%$ & $26 \%$ & $22 \%$ & NA \\
\hline
\end{tabular}

Lower levels of account ownership. While Singapore, Malaysia, Thailand, and Brunei have achieved almost universal financial inclusion, other countries in ASEAN face various challenges (Luna-Martinez 2016). From Table 1, Singapore, Malaysia, and Thailand have financial account penetration of over $75 \%$ while the rest of ASEAN range from $22 \%$ to $34 \%$, which means at least two-thirds of their population do not have a bank account.

Wage payments mostly in cash. Only $29 \%$ of workers reported receiving monthly salaries through an account with a financial institution, and $71 \%$ are paid in cash, risky for employers and workers alike. Paying salary into employees' bank accounts is safer and builds credit histories to access new services, such as consumer credit, mortgages, education loans, and insurance products.

Figure 1 shows Singapore leads with less than $20 \%$ of adults receive wage in cash, followed by Malaysia at less than 50\%, while the rest of ASEAN are over 70\% (no data on Brunei). Singapore is on par with the Organization of Economic Cooperation and Development (OECD) comprising 35 countries. Overall, ASEAN has a higher percentage of adults who receive wage in cash at about $75 \%$ compared to East Asia Pacific at about 65\%. 


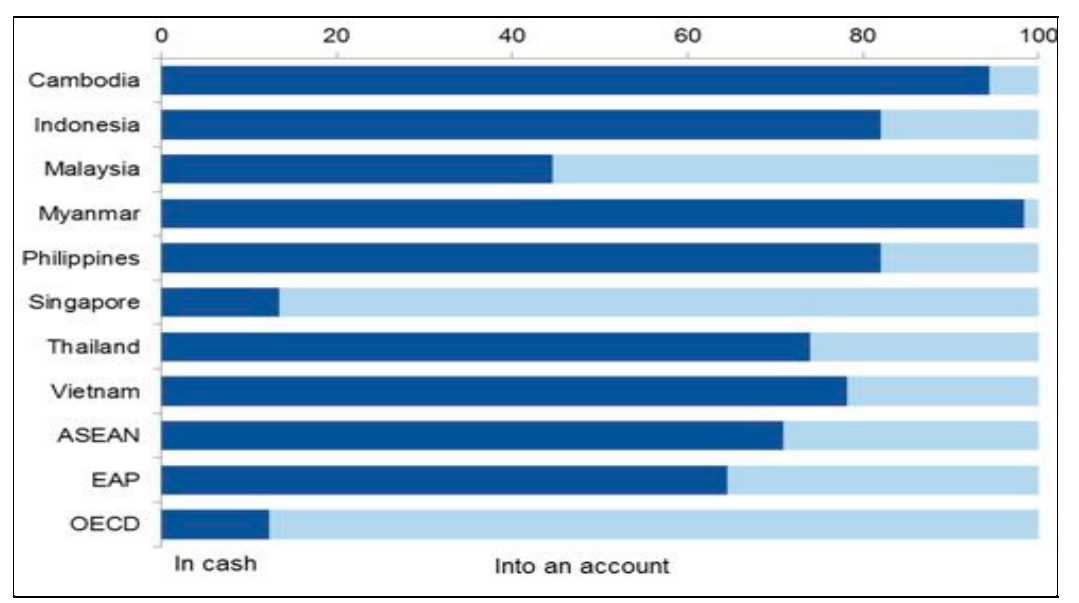

Figure 1. Adults receiving wage payments by method (\%). Source: (Luna-Martinez 2016). “How to scale up financial inclusion in ASEAN countries".

Adoption of Electronic Payment. Only 30\% of adults have a debit card and 9\% have a credit card. Cash is used extensively including those with a bank account. Even among the banked population, penetration of non-cash payment tools is low. Table 2 shows the percent of adults with a debit card, credit card, and whether they are used.

Table 2. Adults with debit card and credit card (\% of Total Adult Population 2014).

\begin{tabular}{|c|c|c|c|c|c|c|c|c|c|c|c|c|c|c|c|c|c|c|}
\hline \multirow{2}{*}{ Card } & \multicolumn{2}{|c|}{ Singapore } & \multicolumn{2}{|c|}{ Malaysia } & \multicolumn{2}{|c|}{ Thailand } & \multicolumn{2}{|c|}{ Indonesia } & \multicolumn{2}{|c|}{ Philippines } & \multicolumn{2}{|c|}{ Vietnam } & \multicolumn{2}{|c|}{ Lao PDR } & \multicolumn{2}{|c|}{ Myanmar } & \multicolumn{2}{|c|}{ Cambodia } \\
\hline & Own & Used & Own & Used & Own & Used & Own & Used & Own & Used & Own & Used & Own & Used & Own & Used & Own & Used \\
\hline Debit & 89 & 78 & 41 & 19 & 58 & 7.9 & 26 & 8.5 & 21 & 12 & 27 & 3.1 & 6 & 2 & 1.7 & 0.4 & 5.4 & 0.7 \\
\hline
\end{tabular}

Source: The Global Findex Database (2017), World Bank. Note: Lao PDR 2011 data. Data is not available for Brunei.

Singapore leads at $89 \%$ with a debit card and $78 \%$ used it, and 35\% with a credit card and $31 \%$ used, followed by Malaysia and Thailand. The rest of ASEAN has below 30\% debit card ownership and below $5 \%$ credit card ownership.

\section{Methodology}

From the above discussion, Singapore has the highest financial inclusion rate and while Fintech businesses continue to grow, it is a matured market with people owning and using multiple credit and debit cards. In contrast, there may be emerging ASEAN nations with a greater need for financial inclusion and offer a bigger opportunity. The objective is to identify the markets with the best potential to grow financial inclusion that attract Fintech investors.

The methodology is similar to evaluating international markets. However, the uniqueness of this methodology is that it does not seek to identify the most advanced Fintech markets but the markets that need financial inclusion most urgently. Hence, the methodology executes the societal marketing philosophy and fulfills the social responsibility mission.

The steps to determine the best growth market in ASEAN for Fintech to promote financial inclusion are described below.

1. Identify the key factors that promote Fintech growth.

2. Gather reliable data for key factors.

3. Determine the scale to rate each factor.

4. Allocate weight for the set of factors.

5. Calculate and compare the scores for the ten ASEAN nations.

6. Determine the best market(s) to grow financial inclusion and maximize equality. 


\subsection{Identify the Key Factors That Promote Fintech Growth}

(Bart and Ayna 2014) proposed three key factors for Fintech success: Selection process and criteria, business support services, and network. Lee and Teoh (2015) identified LASIC for Fintech success: Low margin, asset light, scalable, innovative, and compliance easy. Chen, Chen, Yeh, and Tsaur (Chen et al. 2016) found that Taiwan finance customers had high expectations of information security and preferred high technology products with complex functions, demonstrating the customer's use behavior was influenced by perceived usefulness, not perceived ease of use.

The three studies adopted different approaches from evaluating external to internal factors, from support services and network to easy compliance to customer's perception of usefulness of Fintech facilities. While the discussions of these authors focused on building the success of the Fintech business, there is a need to determine the success factors that help identify the best growth nations in ASEAN that can help influence and accelerate financial inclusion in other ASEAN nations.

Table 3 shows the key factors that influence international market selection based on surveys by UNCTAD, Deloitte and Touche, International Finance Corporation, and FDI Markets (Elms 2017). The far left column categorizes the factors identified from the four surveys.

Table 3. Factors that influence international market selection.

\begin{tabular}{|c|c|c|c|c|c|}
\hline Factor Category & Factors & UNCTAD & $\begin{array}{l}\text { Deloitte } \\
\text { \& Touche }\end{array}$ & $\begin{array}{c}\text { International Finance } \\
\text { Corporation }\end{array}$ & $\begin{array}{c}\text { FDI } \\
\text { Markets }\end{array}$ \\
\hline \multirow{4}{*}{ 1. Market Size } & Market size & Yes & \multirow{4}{*}{ Yes } & & \\
\hline & Access to customers & & & Yes & Yes \\
\hline & Market growth & Yes & & Yes & Yes \\
\hline & Regional market access & Yes & & & \\
\hline \multirow{4}{*}{ 2. Labor Market Efficiency } & Skilled labor & & Yes & \multirow[t]{4}{*}{ Yes } & \multirow[t]{4}{*}{ Yes } \\
\hline & Management staff & & Yes & & \\
\hline & Tech pros & & Yes & & \\
\hline & Labor Cost & Yes & & & \\
\hline 3. Financial Market Development & Capital market access & Yes & & & \\
\hline \multirow{3}{*}{ 4. Institutions } & Government support & \multirow{3}{*}{ Yes } & & Yes & \multirow[t]{2}{*}{ Yes } \\
\hline & Government incentives & & & Yes & \\
\hline & Regulations \& business climate & & & & Yes \\
\hline \multirow{2}{*}{ 5. Stability (Fragile States Index) } & Stability & \multirow[t]{2}{*}{ Yes } & Yes & & \\
\hline & Crime and safety & & Yes & & \\
\hline 6. Ease of Doing Business & Ease of doing business & & Yes & & \\
\hline \multirow{2}{*}{ 7. Infrastructure } & Infrastructure & & & \multirow[t]{2}{*}{ Yes } & \multirow[t]{2}{*}{ Yes } \\
\hline & Utilities & Yes & & & \\
\hline \multirow{2}{*}{ 8. Technological Readiness } & Technology & & & & Yes \\
\hline & Universities \& Researchers & & & & Yes \\
\hline
\end{tabular}

Source: Created by author, adapting from Elms (Elms 2017).

The ING Economics Department (ING Economics Department 2016) developed the fintech index methodology (FIM) comprising three dimensions and four Sub-indices with respective indicators. While the FIM used a set of data to determine the most advanced and commercial Fintech markets, this study seeks to identify the markets that need Fintech most to expand financial inclusion and, thus, needs a different approach in sourcing data to meet this objective.

This methodology undertakes a rigorous procedure to identify the markets with the highest potential to expand financial inclusion urgently to appeal to Fintech entrepreneurs. First, it determines the nations with low penetration and usage of credit and debit cards to facilitate cashless transactions. Second, it determines the most important factors for selecting markets with the best potential for growth such as ease of doing business and infrastructure, from the comparative surveys of four investment-related organizations as shown in Table 3. Third, it identifies sources of information that provide measurements for these factors as shown in the last column data sources in Table 4. 
Table 4. Dimension, sub-index, indicators, and data sources for this study.

\begin{tabular}{|c|c|c|c|c|}
\hline Dimension & Sub-Index & Indicators in ING FIM & Indicators for This Study & Data Sources \\
\hline Demand & $\begin{array}{l}\text { Urgency for } \\
\text { Financial Inclusion }\end{array}$ & $\begin{array}{ll}\text { 1. } & \text { Unbanked } \\
\text { 2. } & \text { Credit gap } \\
\text { 3. } & \text { Poverty } \\
\text { 4. } & \text { Rural population }\end{array}$ & Financial Account Penetration & World Bank \\
\hline \multirow[t]{2}{*}{ Supply } & $\begin{array}{l}\text { Fintech } \\
\text { Infrastructure }\end{array}$ & $\begin{array}{ll}\text { 5. } & \text { Mobile subscription density } \\
\text { 6. } & \text { Internet density } \\
\text { 7. } & \text { Electricity coverage } \\
\text { 8. } & \text { Grid reliability }\end{array}$ & $\begin{array}{ll}\text { 2. } & \text { Mobile telephone subscriptions } \\
\text { 3. Internet users } \\
\text { 4. Quality of Electricity } \\
\text { 5. }\end{array}$ & GCR 2017-2018 \\
\hline & Fintech Ecosystem & 9. Start-up attractiveness & $\begin{array}{ll}\text { 6. } & \text { Ease of doing business } \\
\text { 7. } & \text { Starting a business } \\
\text { 8. } & \text { Market size } \\
\text { 9. } & \text { Labour market efficiency } \\
\text { 10. } & \text { Financial market development }\end{array}$ & $\begin{array}{l}\text { World Bank } \\
\text { (indicators } 6 \text { \& 7) } \\
\text { GCR 2017-2018 } \\
\text { (indicators 8, } 9 \text { \& 10) }\end{array}$ \\
\hline
\end{tabular}

Risk

Political \&
Regulatory

Regulatory

Environment
10. Corruption index

11. Political stability, absence of violence \& terrorism index

12. Strength of legal rights index
11. Institutions

12. Fragile States Index
GCR 2017-2018

(indicator 11)

FSI (indicator 12)

Source: Adapting ING Fintech Index Methodology's indicators with Key Factors for Investment identified by investment surveys as per Table 3. GCR = Global Competitiveness Report by World Economic Forum. FSI = Fragile States Index by Fund for Peace 


\subsection{Gather Reliable Data for Key Factors}

Several global data sources were referenced. The World Competitiveness Yearbook (2017) by the International Institute of Management and Development covers 63 countries but excludes Brunei, Cambodia, Laos, Myanmar, and Vietnam. These countries were, however, included in the global competitiveness report (GCR) 2017-2018 by the World Economic Forum that ranked competitiveness of 137 economies and countries, the Global Findex Database 2017 by World Bank that ranked financial inclusion of 190 countries, and the Fragile States Index 2018 by Fund for Peace that measures the cohesion-economic-political-social stability of 178 countries. Table 4 shows the indicators drawn from these sources to form three dimensions and four sub-indices.

The specific indicators for this study that form the three dimensions and four sub-indices are discussed in the following.

\subsubsection{Demand}

The urgency for financial inclusion is measured by the financial account penetration (FAP) expressed in percentage of adults aged 15+ with a formal account at a bank, credit union, cooperative, post office, or microfinance institution (Kunt and Klapper 2013), available to all population segments irrespective of economic situation (Griffin 2017), especially marginalized rural markets (Lewis and Lindley 2015; Schlein 2017). The cumulative effect of digitally driven financial inclusion could boost GDP by $2 \%$ to $3 \%$ in markets like Indonesia and the Philippines, and 6\% in Cambodia (Asian Development Bank 2014).

\subsubsection{Supply: Fintech Infrastructure}

The internet is dependent on quality of electricity supply, which powers connectivity. Electricity and mobile subscription indicators are provided by the second pillar, infrastructure, and internet user $\%$ population by the ninth pillar, technological readiness, in the global competitiveness report by the World Economic Forum. Technological readiness comprises all the important indicators that support financial inclusion such as fixed broadband internet subscriptions, internet bandwidth, and mobile-broadband subscriptions.

Quality of Electricity Supply (QES) refers to the availability and fitness to power devices important to the success of Fintech businesses. Electricity access refers to the percentage of people with stable access to electricity, and serves as a good proxy for other indicators of wealth and opportunity (Hanania et al. 2018). The 2017 World Bank Enterprise Survey identified electricity services as one of the biggest obstacles to business owners (Doing Business 2018: Reforming to Create Jobs 2018). QES data are provided by the second pillar, infrastructure, in GCR 2017-2018.

Mobile Cellular Telephone Subscriptions provides access to the public switched telephone network (PSTN) using cellular technology. It includes the number of postpaid and active prepaid accounts during the past three months and subscriptions that offer voice communications. It excludes subscriptions via data cards or USB modems, subscriptions to public mobile data services, and private trunked mobile radio, telepoint, radio paging, and telemetry services. (ITU World Telecommunication-ICT Indicators 2017). The second pillar, infrastructure, in the GCR 2017-2018 provides data for mobile cellular telephone subscription per 100 population.

Internet users \% population refers to percent of people using internet from any location or purpose in the last three months via a desktop, laptop or tablet, mobile phone, games machine, and digital TV regardless of fixed or mobile network (GCR 2017-2018). Internet penetration increases trade and income growth (Chu 2013) and a 10\% rise has been reported to increase GDP by 1.08\% (The Economic Times 2015). With smartphones, the internet evolved the banking platform (Andrew 2015) into the internet of things (IoT) facilitating consumer banking, international trade financing, exchange of information, and customer authentication to increase legitimacy of transactions ("Fintech Trends: The Internet of Things," 12 January 2017 (Lazarova 2017)). The ninth pillar, technological readiness, provides data on internet users by \% population, and six other important indicators of Fintech infrastructure. 
For example, Singapore is ranked 25th in internet users due to its small population of 5 million but the other indicators put Singapore in the world's top five: Fifth for internet bandwidth, fourth for mobile broadband subscriptions, and second for FDI and technology transfer.

\subsubsection{Supply: Fintech Ecosystem}

While the ING FIM only provided start-up attractiveness, this study uses several measurements: Ease of doing business, starting a business, market size, labor market efficiency, and financial market development.

Ease of doing business (EDB) represents the reforms a country has undertaken such as infrastructure and legal systems over decades (Javadekar 2017) that influence international confidence (Wijaya 2017). A higher EDB index indicates higher investment friendliness in three ways: (1) Access to economic opportunities such as securing construction permits and electricity, registering property, getting credit, paying taxes, trading across borders, enforcing contracts, and resolving insolvency; (2) lower business set up costs with fewer steps to allow small and medium enterprises (SME) to use finances for post-setup operation; and (3) less corruption as bureaucracy can make official channels vulnerable to corruption, while simplifying the process accelerates economic growth (Naumann 2018). The World Bank's Global Findex Database 2017 provides data for ease of doing business.

Starting a business (SB) measures the paid-in minimum capital requirement, number of procedures, time, and cost for a SME limited liability firm to complete the procedures to start business and formally operate in the country's largest business city. A higher rank indicates more ease in starting a business. Table 5 shows starting a business is harder than doing business in ASEAN, for example, Malaysia' $E D B$ is ranked 24 but SB is 111. (World Bank's Doing Business 2018: Reforming to Create Jobs 2018).

Market Size affects productivity since large markets allows economies of scale (GCR 2017-2018; Ozimek 2016; Aziz and Makkawi 2012). However, population cannot adequately explain market size efficiency; for example, Singapore has a population of 5 million but ranks 35th in market size in the world. The 10th pillar, market size, accounts for strength of domestic market, foreign markets, GDP, and exports as GDP\%. Purchasing power is important to advance Fintech into more sophisticated transaction platforms.

Labor Market Efficiency refers to matching worker skills with suitable jobs and incentivizing human capital development with workers working efficiently and employers providing the right incentives (GCR 2017-2018). The seventh pillar, labor market efficiency, comprises 10 indicators including professional management, talent retention and attraction, effect of taxation, pay, and productivity to support Fintech growth.

Financial Market Developmentis defined as the depth of the intermediation system, including the availability and liquidity of credit, equity, debt, insurances, and other financial products (GCR 2017-2018). The eighth pillar, financial market development, measures eight factors that includes availability and affordability of financial services, ease of access to loans, venture capital availability, soundness of banks, securities of exchange regulations, and legal rights index. 
Table 5. Factors, data source, and scaling method.

\begin{tabular}{|c|c|c|c|c|c|c|}
\hline Dimension and Indicators & \multicolumn{6}{|c|}{ Data Source \& Scaling Method } \\
\hline & \multirow{2}{*}{\multicolumn{6}{|c|}{$\begin{array}{l}\text { The Global Findex Database (2017), World Bank. } 190 \text { Ranks, Rank Range: } 19 \\
\text { Reverse scale is applied: the lower the percent of account penetration, the higher the potential market for Fintech }\end{array}$}} \\
\hline & & & & & & \\
\hline & $0-5$ & 10 & $36-40$ & 6.5 & $71-75$ & 3 \\
\hline Demand & $6-10$ & 9.5 & $41-45$ & 6 & $76-80$ & 2.5 \\
\hline \multirow[t]{6}{*}{ 1. Financial Account Penetration } & $11-15$ & 9 & $46-50$ & 5.5 & $81-85$ & 2 \\
\hline & $16-2$ & 8.5 & $51-55$ & 5 & $86-90$ & 1.5 \\
\hline & $21-25$ & 8 & $56-60$ & 4.5 & 91-95 & 1 \\
\hline & $26-30$ & 7.5 & $61-65$ & 4 & $96-100$ & 0.5 \\
\hline & $31-35$ & 7 & $66-70$ & 3.5 & & \\
\hline & \multicolumn{6}{|c|}{ Note: $\mathrm{AP}=$ Account Penetration } \\
\hline & \multicolumn{6}{|c|}{ Global Competitiveness Index 2017-2018 } \\
\hline Supply: Fintech Infrastructure & \multicolumn{6}{|c|}{137 Ranks, Rank Range: 14} \\
\hline 2. Mobile Cellular Subscription/100 population 2nd Pillar Infrastructure & Rank & Points & Rank & Points & Rank & Points \\
\hline 3. Internet users \% population 9th Pillar Technological Readiness & $1-7$ & 10 & $50-56$ & 6.5 & 99-105 & 3 \\
\hline 4. Quality of Electricity 2nd Pillar Infrastructure & $8-14$ & 9.5 & $57-63$ & 6 & $106-112$ & 2.5 \\
\hline 5. Technological Readiness 9th pillar & $15-21$ & 9 & $64-70$ & 5.5 & $113-119$ & 2 \\
\hline Supply: Fintech Ecosystem & $22-28$ & 8.5 & $71-77$ & 5 & $120-126$ & 1.5 \\
\hline 6. Market Size 10th Pillar & 29-35 & 8 & $78-84$ & 4.5 & $127-133$ & 1 \\
\hline 7. Labor Market Efficiency 7 th pillar- & $36-42$ & 7.5 & $85-91$ & 4 & $134-137$ & 0.5 \\
\hline \multirow[t]{4}{*}{ 8. Financial Market Development 8 th pillar } & $43-49$ & 7 & $92-98$ & 3.5 & & \\
\hline & \multicolumn{6}{|c|}{ The Global Findex Database (2017), World Bank. 190 Ranks, Rank Range 19} \\
\hline & Rank & Points & Rank & Points & Rank & Points \\
\hline & $1-10$ & 10 & $68-76$ & 6.5 & $134-143$ & 3 \\
\hline Supply: Fintech Ecosystem & $11-19$ & 9.5 & $77-86$ & 6 & $144-152$ & 2.5 \\
\hline 9. Ease of Doing Business & $20-29$ & 9 & $87-95$ & 5.5 & $153-162$ & 2 \\
\hline \multirow[t]{6}{*}{ 10. Starting a Business } & $30-38$ & 8.5 & $96-105$ & 5 & $163-171$ & 1.5 \\
\hline & $38-48$ & 8 & $105-114$ & 4.5 & $172-181$ & 1 \\
\hline & $49-57$ & 7.5 & $115-124$ & 4 & $182-190$ & 0.5 \\
\hline & $58-67$ & 7 & $125-133$ & 3.5 & & \\
\hline & \multicolumn{6}{|c|}{$\begin{array}{l}\text { Fragile States Index (2018). } 178 \text { Ranks, Rank Range: } 18 \\
\text { Reverse scale is applied as the higher the rank, the higher the risk }\end{array}$} \\
\hline & Rank & Points & Rank & Points & Rank & Points \\
\hline Risk & $1-9$ & 0.5 & $64-72$ & 4 & $127-135$ & 7.5 \\
\hline 11. Institutions 1st pillar (scale same as Factors 1-7, (Global Competitiveness Report 2017-2018 2017)) & $10-18$ & 1 & $73-81$ & 4.5 & $136-144$ & 8 \\
\hline \multirow[t]{5}{*}{ 12. Fragile States Index (see right column) } & $19-27$ & 1.5 & $82-90$ & 5 & $145-153$ & 8.5 \\
\hline & $28-36$ & 2 & 91-99 & 5.5 & 154-162 & 9 \\
\hline & $37-45$ & 2.5 & $100-108$ & 6 & $163-171$ & 9.5 \\
\hline & $46-54$ & 3 & 109-117 & 6.5 & $172-178$ & 10 \\
\hline & $55-63$ & 3.5 & $118-126$ & 7 & & \\
\hline
\end{tabular}

Note: Ranks = number of nations surveyed by the data source; Rank Range = number of Ranks divided by 10 nations, to nearest whole number. 


\subsubsection{Risk}

FIM measures risk by the political and regulatory environment indexes such as corruption, political stability, and strength of legal rights. These indexes are covered by the first pillar, institutions, in the GCR. Institutions is the first pillar with 21 indicators including strength of investor protection, property rights, judicial independence, efficiency of legal framework in settling disputes and challenging regulations, ethical behavior, and protection of minority shareholders' interest (GCR 2017-2018).

The Fragile States Index (2018) assesses vulnerability comprehensively through four categories with 12 risk indicators: Cohesion (security apparatus, factionalized elites, group grievance), economic (economic decline, uneven economic development, human flight, and brain drain), political (state legitimacy, public services, human rights, and rule of law), and social (demographic pressures, refugees, external intervention).

\subsection{Determine the Scale to Rate Each Factor}

A scale of 1 as lowest to 10 as highest is awarded to the indicator rank for each nation. The scale developed is dependent on the number of countries in each survey, and reverse scaling may be applied, where the higher the rank, the lower the support for financial inclusion.

World Bank's ranking for $\mathbf{1 9 0}$ countries. For ease of doing business and starting a business, the 190 countries are divided by 10 (ASEAN members) and the resulting rank range is 19 . As the rank does not have a decimal, Table 5 shows rank 1 to 10 gains 10 points and 11 to 19 gains 9.5 points, and so on.

The financial account penetration (FAP) shows percent of adult population with a bank account. $100 \%$ divided by 10 yields a range of 10 . Reverse scaling will be applied. Countries with lower FAP have higher potential for financial inclusion. Table 4 shows countries with up to $5 \%$ FAP earns 10 points, $6 \%$ to $10 \%$ earns 9.5 points, and so on. There are no FAP data for Brunei but reporting for World Bank, Luna-Martinez (2016) advised "Singapore, Malaysia, Thailand and Brunei have achieved almost universal financial inclusion ..." Thus, an $82 \%$ penetration is accorded to Brunei, and $81 \%$ to $85 \%$ FAP earns 2 points for Malaysia, Thailand, and Brunei. Data for Myanmar are based on 2014/15 as no later data are available.

Global Competitiveness Report's ranking for 137 countries. With 137 divided by 10, the rank range is 13.7 rounded to 14 . Table 4 shows rank 1 to 7 earns 10 points, rank 8 to 14 earns 9.5 points, and so on. This scale applies to the indicators in:

- Infrastructure: Mobile cellular subscriptions/100 population (second pillar, infrastructure), internet users $\%$ population (ninth pillar, technological readiness), quality of electricity (second pillar, infrastructure), and technological readiness (ninth pillar).

- Ecosystem: Market size (10th pillar), labor market efficiency (seventh pillar), and financial market development (eighth pillar).

- Risk: Institutions (first pillar).

The Fragile States Index's ranking of $\mathbf{1 7 8}$ countries. With 178 divided by 10, the range is 17.8 rounded to 18. Reverse scaling is applied as a higher rank means higher risk. Rank 1 to 9 earns 0.5 points, 10 to 18 earns 1 point, and finally, rank 172 to 178 earns 10 points.

Table 6 shows the FAP and ranks for each financial inclusion indicator, Table 7 shows the weight allocation, and Table 8 shows the respective points allocated for each indicator along with evaluative scores for the market with the best potential for financial inclusion. 
Table 6. Financial account penetration and ranks for financial inclusion indicators.

\begin{tabular}{|c|c|c|c|c|c|c|c|c|c|c|c|c|}
\hline Country & $\begin{array}{c}\text { Financial } \\
\text { Account } \\
\text { Penetration \% }\end{array}$ & $\begin{array}{c}\text { Mobile } \\
\text { Telephone } \\
\text { Subscriptions }\end{array}$ & $\begin{array}{l}\text { Internet } \\
\text { Users }\end{array}$ & $\begin{array}{c}\text { Quality } \\
\text { of } \\
\text { Electricity }\end{array}$ & $\begin{array}{c}\text { Technological } \\
\text { Readiness }\end{array}$ & $\begin{array}{c}\text { Ease of } \\
\text { Business }\end{array}$ & $\begin{array}{l}\text { Starting a } \\
\text { Business }\end{array}$ & $\begin{array}{l}\text { Market } \\
\text { Size }\end{array}$ & $\begin{array}{c}\text { Labour } \\
\text { Market } \\
\text { Efficiency }\end{array}$ & $\begin{array}{c}\text { Financial } \\
\text { Market } \\
\text { Development }\end{array}$ & Institution & $\begin{array}{c}\text { Fragile } \\
\text { State } \\
\text { Index }\end{array}$ \\
\hline Singapore & 98 & 23 & 25 & 3 & 14 & 2 & 6 & 35 & 2 & 3 & 2 & 161 \\
\hline Malaysia & 85 & 28 & 32 & 36 & 46 & 24 & 111 & 24 & 26 & 16 & 27 & 116 \\
\hline Thailand & 82 & 5 & 86 & 57 & 61 & 26 & 36 & 18 & 65 & 40 & 78 & 77 \\
\hline Brunei & 82 & 61 & 43 & 53 & 60 & 56 & 58 & 110 & 47 & 87 & 40 & 124 \\
\hline Indonesia & 49 & 18 & 109 & 86 & 80 & 72 & 144 & 9 & 96 & 37 & 47 & 91 \\
\hline Vietnam & 31 & 44 & 87 & 90 & 79 & 68 & 123 & 31 & 51 & 71 & 79 & 107 \\
\hline Philippines & 34 & 88 & 74 & 92 & 83 & 113 & 173 & 27 & 84 & 52 & 94 & 47 \\
\hline Lao PDR & 29 & 131 & 116 & 75 & 110 & 141 & 164 & 101 & 36 & 75 & 62 & 60 \\
\hline Cambodia & 22 & 52 & 107 & 106 & 97 & 135 & 183 & 84 & 48 & 61 & 106 & 53 \\
\hline Myanmar * & 26 & 135 & 137 & 118 & 138 & 171 & 155 & 60 & 73 & 138 & 133 & 22 \\
\hline
\end{tabular}

Note: Myanmar * data for first eight factors from GCR 2014/15. Financial Account Penetration \% Brunei estimated (Luna-Martinez 2016).

Table 7. Weight allocation for financial inclusion urgency, infrastructure, ecosystem, and risk.

\begin{tabular}{|c|c|c|c|c|}
\hline Dimension & Sub-Index & Indicator for This Study & Weight 1 & Weight 2 \\
\hline Demand & Urgency for Financial Inclusion & 1. Financial Account Penetration & $40 \%$ & $50 \%$ \\
\hline \multirow[t]{2}{*}{ Supply } & Fintech Infrastructure & $\begin{array}{l}\text { 2. Mobile telephone subscriptions } \\
\text { 3. Internet users } \\
\text { 4. Quality of Electricity } \\
\text { 5. Technological Readiness }\end{array}$ & $20 \%$ & $20 \%$ \\
\hline & Fintech Ecosystem & $\begin{array}{l}\text { 6. Ease of doing business } \\
\text { 7. Starting a business } \\
\text { 8. Market size } \\
\text { 9. Labor market efficiency } \\
\text { 10. Financial market development }\end{array}$ & $20 \%$ & $15 \%$ \\
\hline Risk & Political \& Regulatory Environment & $\begin{array}{l}\text { 11. Institutions } \\
\text { 12. Fragile States Index }\end{array}$ & $20 \%$ & $15 \%$ \\
\hline
\end{tabular}

Sources: Created by author, adapting the ING FIM's three dimensions and four sub-indices. 
Table 8. Countries with highest potential for financial inclusion (financial account penetration $50 \%$ ).

\begin{tabular}{|c|c|c|c|c|c|c|c|c|c|c|c|c|c|c|c|c|c|}
\hline \multirow{2}{*}{$\begin{array}{l}\text { Dimension } \\
\text { Country }\end{array}$} & \multicolumn{2}{|c|}{ Demand } & \multicolumn{5}{|c|}{ Supply: Fintech Infrastructure } & \multicolumn{6}{|c|}{ Supply: Fintech Ecosystem } & \multicolumn{3}{|c|}{ Risk } & \multirow[b]{2}{*}{$\begin{array}{l}\text { Total } \\
100 \%\end{array}$} \\
\hline & $\begin{array}{c}\text { Financial } \\
\text { Account } \\
\text { Penetration \% }\end{array}$ & $50 \%$ & $\begin{array}{c}\text { Mobile } \\
\text { Telephone } \\
\text { Subscriptions }\end{array}$ & $\begin{array}{l}\text { Internet } \\
\text { Users }\end{array}$ & $\begin{array}{l}\text { Quality of } \\
\text { Electricity }\end{array}$ & $\begin{array}{l}\text { Technological } \\
\text { Readiness }\end{array}$ & $20 \%$ & $\begin{array}{c}\text { Ease of } \\
\text { Business }\end{array}$ & $\begin{array}{l}\text { Starting a } \\
\text { Business }\end{array}$ & $\begin{array}{l}\text { Market } \\
\text { Size }\end{array}$ & $\begin{array}{c}\text { Labour } \\
\text { Market } \\
\text { Efficiency }\end{array}$ & $\begin{array}{c}\text { Financial } \\
\text { Market } \\
\text { Development }\end{array}$ & $15 \%$ & Institution & $\begin{array}{l}\text { Fragile } \\
\text { State } \\
\text { Index }\end{array}$ & $15 \%$ & \\
\hline Vietnam & 7 & 35 & 7 & 4 & 4 & 5 & 9.8 & 7 & 4 & 8 & 7 & 5 & 9.4 & 5 & 6 & 7.9 & 62 \\
\hline Lao PDR & 8 & 37.5 & 1 & 2 & 5 & 3 & 5.3 & 3 & 2 & 3 & 8 & 5 & 5.6 & 6 & 7 & 9.8 & 58 \\
\hline Cambodia & 8 & 40 & 7 & 3 & 3 & 4 & 7.5 & 3 & 1 & 5 & 7 & 6 & 5.6 & 3 & 3 & 4.1 & 57 \\
\hline Philippines & 7 & 35 & 4 & 5 & 4 & 5 & 8.5 & 5 & 1 & 9 & 5 & 7 & 6.9 & 4 & 3 & 4.9 & 55 \\
\hline Indonesia & 6 & 27.5 & 9 & 3 & 4 & 5 & 10 & 7 & 3 & 10 & 4 & 8 & 8.3 & 7 & 6 & 9.4 & 55 \\
\hline Singapore & 1 & 2.5 & 9 & 9 & 10 & 10 & 18.3 & 10 & 10 & 8 & 10 & 10 & 14.3 & 10 & 9 & 14.3 & 49 \\
\hline Malaysia & 2 & 10 & 9 & 8 & 8 & 7 & 15.5 & 9 & 5 & 9 & 9 & 9 & 11.4 & 9 & 7 & 11.3 & 48 \\
\hline Myanmar & 8 & 37.5 & 1 & 1 & 2 & 1 & 1.8 & 2 & 2 & 6 & 5 & 1 & 5.4 & 1 & 2 & 1.9 & 47 \\
\hline Brunei & 2 & 10 & 6 & 7 & 7 & 6 & 12.8 & 8 & 7 & 3 & 7 & 4 & 9.0 & 8 & 7 & 10.9 & 43 \\
\hline Thailand & 2 & 10 & 10 & 4 & 6 & 6 & 13 & 9 & 9 & 9 & 6 & 8 & 12.0 & 5 & 5 & 6.8 & 42 \\
\hline
\end{tabular}

Source: Points allocated by ranks from Global Findex Database (2017), Global Competitiveness Report 2017-2018 2017 (2017); Fragile States Index (2018). 


\subsection{Allocate Weight for the Set of Factors}

If the 12 factors have equal weight, Singapore would top the list. While sophisticated Fintech businesses can flourish, there is little room for financial inclusion as Singaporeans have a high FAP with high debit and credit cards ownership and usage.

As the goal is to achieve maximum financial inclusion to overcome inequality, demand is the most important factor to begin with: Financial account penetration (FAP). Table 7 below shows two weight approaches to identify the best growth potential markets for financial inclusion.

The first approach allocates $40 \%$ to FAP (demand) for financial inclusion urgency, and $20 \%$ each to infrastructure and ecosystem (supply) and political and regulatory nvironment (Risk). The second approach allocates $50 \%$ to $\mathrm{FAP}, 20 \%$ to infrastructure, and 15\% each to ecosystem and political and regulatory environment.

\subsection{Calculate and Compare the Scores for the Ten ASEAN Nations}

When $40 \%$ weight was applied, the results from highest to lowest potential for financial inclusion: Vietnam, Singapore, Lao PDR, Indonesia, Malaysia, Cambodia, Philippines, Brunei, Thailand, and Myanmar. As discussed earlier, Singapore and Malaysia have achieved high financial inclusion, which does not achieve the objective of this study. Incremental weight at $45 \%$ was applied but yielded similar results.

In Table 7, the points are allocated according to the rank of each indicator and the corresponding weight for each dimension (Table 5). When $50 \%$ was applied to FAP, a significantly different result emerged as shown in Table 8.

\subsection{Determine the Best Market(s) to Grow Financial Inclusion and Maximize Equality}

Vietnam, Lao PDR (Laos), and Cambodia are the top three markets for financial inclusion. The Philippines and Indonesia are fourth and fifth.

\subsubsection{Discussion}

Vietnam, Laos, and Cambodia are the emerging markets in ASEAN that need help to reduce inequality through financial inclusion. Table 9 shows the sector share of GDP (\% 2011) of the three countries, all with agriculture $35 \%$ or more, suggesting a high rural population that suffers financial exclusion. Cambodia is highest in services at $43 \%$, followed by Laos at 37\%, while Vietnam is highest in industry at $41 \%$.

Table 9. Sector share of real gross domestic product (GDP) $(\%, 2011)$.

\begin{tabular}{cccc}
\hline & Vietnam & Lao PDR & Cambodia \\
\hline Agriculture & $39 \%$ & $43 \%$ & $35 \%$ \\
\hline Services & $20 \%$ & $37 \%$ & $43 \%$ \\
\hline Industry & $41 \%$ & $20 \%$ & $21 \%$ \\
\hline
\end{tabular}

Source: Doubling Financial Inclusion in the ASEAN Region by 2020, UNCDF.

\subsubsection{Opportunities}

Ensuring adults have access to a bank account is a first step toward comprehensive financial inclusion, where people can make use of appropriate financial services, including savings, payments, credit, and insurance (Pazarbasiogl 2017). Table 10 shows the summary of supply and demand of financial services of the three countries based on the UNCDF's Doubling Financial Inclusion in the ASEAN Region by 2020. The data show great potential in all three countries to grow financial inclusion. 
Table 10. Summary of supply and demand of financial services.

\begin{tabular}{|c|c|c|c|c|}
\hline & Country & Cambodia & Laos & Vietnam \\
\hline & Population & 16.3 Million & 6.9 Million & 96.5 Million \\
\hline \multirow{2}{*}{$\begin{array}{l}\text { Method of savings } \\
\text { (aged 15+, 2011) }\end{array}$} & Financial institution & 0.8 & 19.4 & 7.7 \\
\hline & Savings club & 4.3 & 8.1 & 5.1 \\
\hline \multirow{4}{*}{$\begin{array}{l}\text { Population having a } \\
\text { bank account } \\
(\%, 2011)\end{array}$} & Urban & 10.2 & 32 & 29.8 \\
\hline & Rural & 2.4 & 20.2 & 16.5 \\
\hline & Aged 15-24 & 4.5 & 23 & 22.6 \\
\hline & Aged 25+ & 3.3 & 28.5 & 21.1 \\
\hline \multirow{4}{*}{$\begin{array}{l}\text { Mobile use } \\
(\%, 2011)\end{array}$} & Mobile penetration & 96 & 87 & 99 \\
\hline & Mobile use to pay bills & 0.1 & 0 & 3.6 \\
\hline & Mobile use to receive money & 0.6 & 0 & 3.4 \\
\hline & Mobile use to send money & 0.4 & 0 & 2.8 \\
\hline \multirow{7}{*}{$\begin{array}{l}\text { Banking sector } \\
\text { statistics (2010) }\end{array}$} & Number of banks & 36 & 26 & 101 \\
\hline & Market share of state-owned banks & 0 & 67.4 & 47.7 \\
\hline & Number of branches & 360 & 83 & 1988 \\
\hline & Number of ATMs & 501 & 346 & 11700 \\
\hline & Number of branches (per 100,000 adults) & 4 & 2.6 & 3.3 \\
\hline & Number of ATMs (per 100,000 adults) & 5.1 & 4.3 & 17.6 \\
\hline & Assets/GDP ratio (\%) & 58 & 49.7 & 14 \\
\hline
\end{tabular}

Source: Doubling Financial Inclusion in the ASEAN Region by 2020, UNCDF. Population data from (Worldometers 2018).

Table 10 shows the following financial inclusion opportunities:

- Method of savings (\% population aged 15+): All three countries have less than $20 \%$ who saved with a financial institution. Laos has twice more savers in a financial institution at nearly $20 \%$ than Cambodia and Vietnam.

- Population with a bank account: Rural dwellers are twice lower than urban dwellers in a bank account ownership.

- Banking sector statistics: There are insufficient bank branches to meet needs. Cambodia leads by four branches per 100,000 adults. Laos has $67.4 \%$ market share of state-owned banks followed by Vietnam $47.7 \%$ but nil for Cambodia. Laos has the highest population of formally banked at nearly $20 \%$ but lowest in branches and ATMS per 100,000 adults.

- Mobile use: Despite mobile penetration from $87 \%$ upwards, mobile use to pay bills, receive, or send money is $0 \%$ in Laos, below $1 \%$ in Cambodia, and below $5 \%$ in Vietnam. There is great potential for mobile banking.

The data above provide a vast opportunity for growth in financial inclusion in the three countries. The following discusses the initiatives in each country to expand financial inclusion.

\subsubsection{Vietnam}

Vietnam has 96.5 million people and a density of 299 people per sq. $\mathrm{km}$ (compared to 8188 per sq. $\mathrm{km}$ in Singapore). Financial account penetration is $31 \%$ and $27 \%$ own a debit card and $1.9 \%$ a credit card (The Global Findex Database 2017, World Bank). Vietnam has the highest number of banks, bank branches, and ATMs compared to Laos and Cambodia.

Since 2016, the State Bank of Vietnam and World Bank have partnered to focus on shifting government payments to digital platforms, providing financial services to ethnic minorities and 
agricultural communities where poverty rates are above national average, and strengthening financial education to prepare the next generation for a modern financial marketplace.

Vietnam is among World Bank's 25 priority countries for financial inclusion efforts, where $39 \%$ of adults save outside the formal sector such as "under the mattress" or use informal savings clubs, and $65 \%$ send or receive remittances, and pay school fees or utility bills in cash. Some of the barriers to formal financial services include:

- Financial services are too far to access-6.2 million adults;

- Financial services are too expensive to use-2.2 million adults;

- Documentation requirements are prohibitive to open an account-2.3 million adults;

- Lack of trust in the financial sector-1.1 million adults.

Removing these barriers through appropriate legal and regulatory reforms can help move consumers from the informal to formal financial sector with great effect, as an improved policy environment could mean an estimated 48 million adults with transaction accounts. Furthermore, government-to-person (G2P) cash transfers can be digitized to reach an additional 3.7 million currently unbanked adults.

\subsubsection{Lao PDR}

Lao People Democratic Republic (Laos) has 6.9 million people with a density of 30 people per sq. $\mathrm{km}$. An agricultural society with $80 \%$ of population in rural areas, the landlocked landscape of thick forests, rugged mountains, and fast flowing rivers makes physical and economic connectivity between communities difficult. Small-scale subsistence agriculture accounts for over 30\% of GDP and employs $70 \%$ of population. In rural upland areas, the poverty rate is $43 \%$ compared with $28 \%$ in the lowlands. A mere $20 \%$ of the population in the lower $40 \%$ income segment have a formal bank account (Internationale Zusammenarbeit (GIZ)).

While Laos has experienced economic growth over the last decade, inequality has risen and financial inclusion remains low. Access to financial institutions is limited to $29 \%$ of population, $6 \%$ own a debit card, and 3\% credit card (The Global Findex Database 2017). Laos has the third-lowest level of financial access in ASEAN (only Cambodia and Myanmar rank lower). Laos is working on increasing the supply of financial services such as access to ATMs and financial literacy programs.

To increase financial inclusion, the authorities introduced "Community Money Express" in 2015 to allow microfinance institutions to utilize commercial banks' branches to expand reach in the largely rural and agrarian country, a service launched by Banque pour le Commerce Exterieur Lao Public (BCEL), one of the country's leading banks. The UNCDF, in collaboration with the Bank of Lao PDR and Central Bank, have worked to design several initiatives:

- Making access to finance more inclusive for poor people to improve policy and regulatory environment, financial infrastructure, and capacity of financial service providers.

- Making access possible through evidence-based financial inclusion policy framework to diagnose financial inclusion disaggregated by gender, geographic location, and income level.

- Shaping inclusive finance transformations to accelerate financial inclusion and women's economic participation (UNCDF 2017).

\subsubsection{Cambodia}

Cambodia has 16.3 million people with a density of 92 people per sq. $\mathrm{km}$. Financial account penetration is $22 \%$ and $5.4 \%$ with credit cards and $2.9 \%$ debit cards (The Global Findex Database 2017). In 2016, the United Nations Capital Development Fund (UNCDF) and partners conducted a survey on the accessibility and usage of Cambodian financial services among 3150 adults. The findings show:

- Financial exclusion: $29 \%$ use neither formal nor informal financial services.

- Informal services: Over one-third of the population use unregistered lenders or savings clubs. 
- Formal inclusion: $59 \%$ with $24 \%$ of these using microfinance institutions (MFIs) and $17 \%$ banks; females $73 \%$ compared to males $69 \%$; urban areas $74 \%$ and rural areas $69 \%$.

- Access financial infrastructure: $75 \%$ in rural areas take over $30 \mathrm{~min}$ to access post offices, bank branches, and ATMs.

- Borrowings: $58 \%$ do not borrow to avoid debt; $54 \%$ turn to MFIs; $22 \%$ borrow from family and friends; $14 \%$ from a bank.

- Savings at time of survey: Over $50 \%$ no savings with $86 \%$ of these claiming no money left after basic living expenses.

- Those who save: Kept money at home or a secret hiding place, while 31\% invested in livestock; $21 \%$ bought gold or jewelry for future re-sale profit. (MacGrath 2016).

Microfinance is used as a key driver of financial inclusion. The Cambodian Microfinancing program aims to increase financial literacy, improve governance and transparency, regulate the financial sector, and make financial services more affordable. Oxfam (2013), a global charitable organization, introduced savings-for-change (SfC) as a pro-poor savings-led microfinance product, and in 2017, over 140,000 people saved USD 5.7 million and 40 local organizations received training to provide the product. SfC is a community-organizing tool to support women transformative leadership to challenge social norms. Oxfam developed two approaches on financial inclusion and economic strengthening of poor women farmers and their families. The single approach provides financial services (loans and credits) for poor women and their families and financial education of households. The integrated approach provides skills-based education (financial literacy with social/life skills) and service on financial inclusion (SfC Group, MFIs, and banking).

Giving women access to affordable financial credit/savings, such as SfC groups, helps to boost self-esteem and leadership capacity, improve income and livelihoods through loans or share outs, invest in farms or businesses to increase household income and security, and create sustainable wellbeing for poor women and their families.

Like their work in Laos, UNCDF has designed similar programs to help increase financial inclusion in Cambodia:

- Shaping inclusive finance transformations to accelerate financial inclusion and women's economic participation, and advocate pro-poor policies, utilize big data analysis of Cambodia's top banks to understand customer service needs and gaps; invest in innovative business models to expand women's economic participation.

- Making access possible expands financial access for rural populations, and micro and small businesses.

- YouthStart Global convenes stakeholders to provide economic opportunities geared toward youth, including capacity-building in opportune sectors, increased access to financial and non-financial services, and access to information on integrated services available to youth.

- CleanStart supports clean energy policy development, and provides risk capital and technical assistance to competitively selected financial service providers and energy enterprises. This initiative supports low-income consumers to transition to cleaner and more efficient energy through access to financial services and payment mechanisms and will help contribute to achieving development goals on poverty and hunger, education, gender, health, and environmental sustainability.

\subsubsection{Interventions with Most Impact}

In a UNCDF consultation with CLMV market-leaders in financial inclusion, the participants were requested to rate the interventions with the greatest impact on improving the level of financial inclusion in each market. Points were allocated for each intervention out of a total of 100 for each country. Table 11 shows the interventions that participants rated as having the most impact and the explanations of these outcomes are presented below. 
Table 11. The interventions that will double the level of financial inclusion by 2020 .

\begin{tabular}{lrrr}
\hline Intervention & Cambodia & Laos & Vietnam \\
\hline Improved function of state FI & 4 & $\mathbf{1 1}$ & $\mathbf{1 3}$ \\
Government payments & 11 & 10 & 11 \\
Regulatory & 10 & 16 & 18 \\
New distribution models & $\mathbf{2 1}$ & 11 & 10 \\
Mobile & $\mathbf{2 3}$ & $\mathbf{1 8}$ & 14 \\
Microfinance extension & 16 & 19 & 19 \\
Demand analysis & 15 & 15 & 15 \\
Total & 100 & 100 & 100 \\
\hline
\end{tabular}

Source: Doubling Financial Inclusion in the ASEAN Region by 2020, UNCDF.

- In Laos and especially Vietnam, state financial institutions play an important role in increasing financial inclusion. However, participants face challenges with securing appropriate engagement with state institutions to discuss financial inclusion.

- Leveraging the role of Government payments in promoting financial inclusion will be significant in all three markets but will generally account for less than $10 \%$ of progress towards the targets.

- Regulatory change is needed especially in Laos and Vietnam to progress in financial inclusion.

- New distribution models such as outsourced or non-branch based services were considered most important in Cambodia.

- For mobile-based service delivery, Cambodia and Laos offer the greatest potential for impact.

- Extending microfinance is highly significant for all three markets.

- Appropriate demand analysis needs to precede intervention efforts.

\subsubsection{Risk and Investor Profiles}

While the emerging nations of Vietnam, Laos, and Cambodia present exciting growth opportunities in financial inclusion, they also present risks associated with Fintech infrastructure, Fintech ecosystem, or stability. The ING Economics Department (2016) identifies three types of investors.

Commercial investors seek maximum return on investments. Risk-averse investors prefer a stable economy and the right ecosystem. Risk-loving investors are more willing to balance the risk with higher gains with markets that provide larger growth opportunities. These investors are generally investment funds and venture capitalists.

Social investors want to create both social impact and a financial return, seeking "double-bottom line" results. They are usually not-for-profit and for-profit funds, investment vehicles, government sponsored organizations, development banks, and social enterprises.

Donor organizations focus on maximizing social returns and are likely to invest in countries where financial exclusion is highest. They seek to identify the economies that have a better capacity to absorb their funds to create the most impact.

As a summary, the investors who may find Vietnam, Laos, and Cambodia as attractive markets for their funds will be donor organizations, followed by social investors, and risk-loving commercial investors.

\section{Limitations}

The main limitation is the availability of data of some nations. This may be due to political instability that prevent data gathering or a lack of research partners to collect the data in some nations. While care has been taken to ensure relevant data to help in evaluating markets with the best potential for financial inclusion, The Global Findex Database (2017) did not provide data on Brunei. Based on a World Bank online article that Brunei has achieved almost universal financial inclusion along with 
Singapore, Malaysia, and Thailand, Brunei was allocated the same points as Malaysia and Thailand since Singapore is ahead in financial inclusion.

The findings support the UNCDF's efforts to expand financial inclusion in the CLMV. However, Myanmar did not surface in the results and instead the Philippines and Indonesia emerged as fourth and fifth most potential markets. This may be due to the fact that Myanmar's data were dated to 2014/2015 and may have changed since Myanmar won democracy in March 2016. Nevertheless, the Philippines and Indonesia are justified as two markets with high growth potential considering their huge populations of 103 million and 260 million, respectively, with many people facing financial exclusion living in the thousands of islands that make up each country,

Another limitation may be the conventional approach to maximize profit from investments. The findings present the conflict between maximizing social impact and financial returns. Singapore is the best market with state-of-the-art infrastructure and strong governance but offers little room to grow financial inclusion. The likely investors for Vietnam, Laos, and Cambodia would be donor organizations that seek to maximize social returns, followed by social investors who seek a mix of financial and social returns, and lastly, risk-loving commercial investors who prioritize higher gains in markets with larger growth opportunities.

\section{Conclusions and Recommendations}

The main contribution of this research lies in its originality of a research that seek not to maximize financial profit but financial inclusion for people in dire need for banking facilities to alleviate poverty and improve quality of life. This research fulfills the social responsibility mission while it offers high growth markets to Fintech entrepreneurs. While other research and their respective methodologies seek to determine the most advanced and commercial Fintech markets for gain, this research adopts rigorous filters that analyzes empirical data that identify (1) markets with lowest financial inclusion via data of ownership and usage of debit cards, (2) the most important investment attractiveness factors integrating findings from four reputable investment-related organizations, and (3) sources of information that provide measurements to the investment attractiveness factors. Fintech entrepreneurs who capitalize on this research's findings will reap returns from largely untapped markets while they help to achieve societal marketing goals.

The research also contributes to the economic growth of the nation. Governments with poor ratings such as in governance and risk indicators can take measures to improve the relevant factors, and devise investment incentives to draw foreign investment. Another contribution is the potential collaboration with economists and other specialists who analyze such data to propose policy to their governments which in turn need to operationalize the policy. This research operationalizes the constructs of risk, demand, and supply to draw investments to expand financial inclusion that will stimulate economic growth and stability. This research's methodology is a first to identify the best growth markets for financial inclusion that will appeal to Fintech entrepreneurs with profit or altruistic motivations, to help narrow the gap in income equality within a nation and between nations. The step-by-step market selection methodology based on empirical analysis makes it easier for investors to follow than econometric models that may limit the discussion to and among economists. Integrating the expertise of economists and marketing specialists may create research that build growth models for the nation.

There are two recommendations for future research. The first proposal is to investigate from the consumer perspective the reasons for low ownership and usage of debit cards. Except for Singapore with $89 \%$ of adult population owning a debit card followed by Thailand at $58 \%$ and Malaysia $41 \%$, the rest are $25 \%$ or below. As for debit card usage, the statistics are even lower. For example, Thailand has $58 \%$ debit card ownership, higher than Malaysia at $41 \%$. However, only $8 \%$ of Thais use a debit card compared to $19 \%$ of Malaysians. Except for Singapore, Malaysia and the Philippines were over $50 \%$ of debit card owners using the debit card, while the rest of ASEAN have less than $10 \%$ using the debit card although a larger percentage own a debit card. 
Could one reason be the multitude of small businesses such as food vendors in Thailand who need cash to buy supplies to make food? If so, what conditions may allow the provision of handheld credit/debit card terminals to such vendors? What can governments do to promote a cashless society in a country where small businesses are the spine of the economy?

Singapore, Malaysia, and the Philippines use English as the official business language. Is there evidence that English helps accelerate the usage of debit cards, and financial inclusion in the ASEAN context? ASEAN people, like other Asian nations, have a Confucian philosophy of saving for the future. A perceptual and attitudinal study on cashless transactions may help uncover reasons for the low debit card usage.

The second recommendation is to investigate the challenges of financial inclusion from both industry and governance perspectives. Finance is an industry vulnerable to disruption by software because financial services are made of information rather than concrete goods. Data security remains a threat as regulators are concerned with hacking and the need to protect sensitive consumer and corporate financial data. Any data breach can ruin a Fintech firm's reputation. The Bank Secrecy Act and money transmission regulations represent an ongoing threat to Fintech companies.

Blockchains can help lower cost of transaction by sharing a digital ledger among competitors with the assurance that cryptocurrencies have a permanent record of transfers and ownership free from being tampered or hacked. Cryptocurrency, however, faces low consumer confidence as a practical and trusted currency for transaction. Moving data to the cloud may sound safe but seems risky as any online platform suffers the risk of hacking.

As the industry explores products and services based on innovations, diminishing margins is the most likely challenge in the face of increasing competition. There is greater operational risk in maintaining virtual operations, vulnerable to money-laundering and terrorism financing activities. The online financial sector is also an increasing target of distributed denial of service extortion attacks. Fintech companies often face doubts from financial regulators like issuing banks and the Federal Government. The research can identify the challenges and make recommendations how the industry and government could collaborate to balance the need for financial inclusion with the need for consumer and corporate data protection.

Funding: This research received no external funding.

Conflicts of Interest: The authors declare no conflicts of interest.

\section{References}

Andrew, Ryan. 2015. The Impact of Mobile on the Evolution of Fintech. Available online: https://www.gsma.com/ digitalcommerce/the-impact-of-mobile-on-the-evolution-of-fintech (accessed on 13 December 2017).

Asian Development Bank. 2014. Accelerating Financial Inclusion South-East Asia with Digital Finance. Philippines: ADB.

Aziz, Abdul, and Bilal Makkawi. 2012. Relationship between Foreign Direct Investment and Country Population. International Journal of Business and Management 7. [CrossRef]

Bart, Clarysse, and Yusubova Ayna. 2014. Technology Business Incubation Mechanisms and Sustainable Regional Development, Proceedings. October 23. Available online: http://hdl.handle.net/1854/LU-6842877 (accessed on 30 November 2019).

Bruhn, Miriam, and Inessa Love. 2009. The economic Impact of Expanding Access to Finance in Mexico (English). Finance \& PSD Impact Evaluation Note; No. 9. Washington, DC: World Bank, Available online: http://documents.worldbank. org/curated/en/607591468280440182/The-economic-impact-of-expanding-access-to-finance-in-Mexico (accessed on 30 November 2019).

Burgess, Robin, and Rohini Pande. 2005. Do Rural Banks Matter? Evidence from the Indian Social Banking Experiment. American Economic Review 95: 780-95. [CrossRef]

Chen, Ming-Chih, Shih-Shiunn Chen, Hung-Ming Yeh, and Wei-Guang Tsaur. 2016. The Key Factors Influencing Internet Finances Services Satisfaction: An Empirical Study in Taiwan. American Journal of Industrial and Business Management 6: 748-62. [CrossRef]

Chu, Shan-Ying. 2013. Internet, Economic Growth and Recession. Modern Economy 4: 209-13. [CrossRef] 
Cull, Robert, Tilman Ehrbeck, and Nina Holle. 2014. Financial inclusion and development: Recent impact evidence. In Focus Note. Washington, DC: CGAP, vol. 92.

Demetriades, Panicos, and Siong Hook Law. 2006. Finance, institutions and economic development. International Journal of Finance and Economics 11: 245-60. [CrossRef]

Doing Business 2018: Reforming to Create Jobs. 2018. A World Bank Group Flagship Report. The World Bank Group. Available online: http://documents.worldbank.org/curated/en/803361509607947633/Doing-Business2018-Reforming-to-Create-Jobs (accessed on 29 November 2019).

Elms, Gregory. 2017. International Investments. Presentation by Gregory A. Elms, Field Director, Canada-Indonesia Trade and Private Sector Assistance Project (TPSA) at BINUS International Campus, Jakarta, Indonesia. December 4.

Fragile States Index. 2018. The Fund for Peace. Available online: https://fragilestatesindex.org/ (accessed on 29 November 2019).

Global Competitiveness Report 2017-2018. 2017. The World Economic Forum. Available online: http://www3.weforum. org/docs/GCR2017-2018/05FullReport/TheGlobalCompetitivenessReport2017\%E2\%80\%932018.pdf (accessed on 29 November 2019).

Griffin, Oliver. 2017. How Fintech is Increasing Financial Inclusion. Raconteur. Available online: https://www. raconteur.net/finance/how-fintech-is-increasing-financial-inclusion (accessed on 29 November 2019).

Hanania, Jordan, Kailin Stenhouse, and Jason Donev. 2018. Energy Education: Access to Electricity. June 25. Available online: http://energyeducatfubion.ca/encyclopedia/Access_to_electricity (accessed on 29 November 2019).

ING Economics Department. 2016. The Fintech Index: Assessing Digital and Financial Inclusion in Developing and Emerging Countries. The ING Group. Available online: https://www.ing.nl/media/ING_EBZ_fintechindex-report_tcm162-116078.pdf (accessed on 29 November 2019).

Internationale Zusammenarbeit (GIZ) GmbH. 2012. Rural Finance in Laos: GIZ Experience in Remote Rural Access. Available online: https://www.microfinancegateway.org/sites/default/files/mfg-en-paper-rural-finance-inlaos-giz-experience-in-remote-rural-areas-dec-2012.pdf (accessed on 29 November 2019).

ITU World Telecommunication-ICT Indicators. 2017. World Telecommunication/ICT Indicator Database. Available online: https://www.itu.int/en/ITU-D/Statistics/Pages/publications/wtid.aspx (accessed on 29 November 2019).

Javadekar, Apoorva. 2017. Why the Ease of Doing Business Matters: Livemint. Available online: http://www. livemint.com/Opinion/ZFP18NIFA18Up0s8FPQySL/Why-the-ease-of-doing-business-matters.html (accessed on 29 November 2019).

Kunt, Asli Demirgüç, and Leora Klapper. 2013. Measuring Financial Inclusion: Explaining Variation in Use of Financial Services across and within Countries. The World Bank. Available online: http://siteresources.worldbank.org/ EXTDEC/Resources/469371-1367338460733/Brookings_Apr28.pdf (accessed on 29 November 2019).

Lagarde, Christine. 2018. ASEAN and the IMF: Working Together to Foster Inclusive Growth. Available online: https://www.imf.org/en/News/Articles/2018/02/25/sp022718-jakarta-MD-asean-and-the-imf-workingtogether-to-foster-inclusive-growth (accessed on 29 November 2019).

Lazarova, Dara. 2017. Fintech trends: The Internet of Things. January 12. Available online: https://www.finleap. com/insights/fintech-trends-the-internet-of-things/ (accessed on 30 November 2017).

Lee, David Kuo Chuen, and Gin Swee (Zhang Jinrui) Teoh. 2015. Emergence of FinTech and the LASIC principles. Journal of Financial Perspectives 3: 24-36. [CrossRef]

Levine, Ross. 2000. Finance and Growth: Theory and Evidence. In Handbook of Economic Growth, 1st ed. Edited by Philippe Aghion and Steven Durlauf. Amsterdam: Elsevier, vol. 1.

Lewis, Sue, and Dominic Lindley. 2015. Financial Inclusion, Financial Education and Financial Regulation in the United Kingdom. ADB Working Paper Series 544; Tokyo: Asian Development Bank Institute.

Luna-Martinez. 2016. How to Scale up Financial Inclusion in ASEAN Countries. The World Bank. Available online: https://blogs.worldbank.org/eastasiapacific/how-to-scale-up-financial-inclusion-in-asean-countries (accessed on 29 November 2019).

MacGrath. 2016. New Tool for Financial Inclusion. The Phnom Penh Post. Available online: https://www. phnompenhpost.com/business/new-tool-financial-inclusion (accessed on 13 July 2016).

McKinsey and Company. 2016. Challenges and Opportunities for Fintech in Germany. Available online: https: //www.mckinsey.com/industries/financial-services/our-insights/fintech-challenges-and-opportunities (accessed on 29 November 2019). 
Nanda, Kajole, and Mandeep Kaur. 2016. Financial Inclusion and Human Development: A Cross-Country Evidence. Management and Labour Studies 41: 127-53. [CrossRef]

Naumann, Friedrich. 2018. 3 Reasons Why Ease of Doing Business in a Country is Important. The Friedrich Naumann Foundation for Freedom. Available online: http://asia.fnst.org/content/3-reasons-why-ease-doing-businesscountry-important (accessed on 29 November 2019).

Oxfam. 2013. Saving for Change: Financial Inclusion and Resilience for the World's Poorest People. Oxfam America, May. Available online: https://www.oxfamamerica.org/static/oa4/oxfam-america-sfc-ipa-baratoplines.pdf(accessed on 29 November 2019).

Ozimek, Adam. 2016. Why Is Population Growth Good for Businesses? Available online: https://www.forbes.com/ sites/modeledbehavior/2016/10/23/why-is-population-growth-good-for-businesses/\#4ff10a10297f (accessed on 23 October 2016).

Park, Cyn-Young, and Rogelio Mercado. 2015. Financial Inclusion, poverty and Income Inequality in Developing Asia. Available online: https://ssrn.com/abstract=2558936orhttp://dx.doi.org/10.2139/ssrn.2558936 (accessed on 29 November 2019).

Pasali, Selahattin Selşah. 2013. Where Is the Cheese? Synthesizing a Giant Literature on Causes and Consequences of Financial Sector Development. Washington, DC: The World Bank.

Pazarbasiogl, Ceyla. 2017. Vietnam's Financial Inclusion Priorities: Expanding Financial Services and Moving to a 'Non-Cash' Economy. The World Bank. Available online: https://blogs.worldbank.org/voices/vietnam-sfinancial-inclusion-priorities-expanding-financial-services-and-moving-non-cash-economy (accessed on 29 November 2019).

Ruiz, Claudia. 2013. From Pawnshops to Banks. The Impact of Formal Credit on Informal Households. Washington, DC: The World Bank.

Sarma, Mandira. 2008. Index of Financial Inclusion. Indian Council for Research on International Economic Relations. Available online: http://www.icrier.org/pdf/Working_Paper_215.pdf (accessed on 29 November 2019).

Schlein, Michael. 2017. Fintech's Potential for Financial Inclusion: MoneyConf Panel. Accion Ventures. Available online: https://medium.com/accion/moneyconf-panel-fintechs-potential-for-financial-inclusion-87adaba1cd1d (accessed on 29 November 2019).

The Economic Times. 2015. How Internet Users Will Impact These Five Areas. February 26. Available online: https://economictimes.indiatimes.com/tech-life/how-internet-users-will-impact-these-five-areas/ economy-financial-inclusion/slideshow/46376647.cms (accessed on 30 November 2019).

The Global Findex Database. 2017. Global Findex: The World Bank. Available online: https:/globalfindex.worldbank. org/ (accessed on 29 November 2019).

UNCDF. 2017. Doubling Financial Inclusion in the ASEAN Region by 2020. Available online: http://www.finmark.org. za/wp-content/uploads/2016/01/ASEAN_doubling_financial_inclusion.pdf (accessed on 29 November 2019).

Wijaya, Ahmad. 2017. Investors Want Ease of Doing Business and Legal Certainty. ANTARA News. Available online: https://en.antaranews.com/news/113532/investors-want-ease-of-doing-business-and-legal-certainty (accessed on 29 November 2019).

World Bank. 2016. Financial Access. Available online: https://www.worldbank.org/en/publication/gfdr/gfdr-2016/ background/financial-access (accessed on 30 November 2019).

World Bank. 2019. Financial Inclusion Is the Key to Enabler to Reducing Poverty and Boosting Prosperity. Available online: https://www.worldbank.org/en/topic/financialinclusion/overview/ (accessed on 28 November 2019).

World Competitiveness Yearbook. 2017. IMD Competitiveness Ranking 2017: IMD World Competitiveness Center. Available online: https://www.imd.org/wcc/world-competitiveness-center-rankings/competitiveness-2017rankings-results/ (accessed on 29 November 2019).

Worldometers. 2018. Available online: http://www.worldometers.info/ (accessed on 15 June 2018).

(C) 2019 by the author. Licensee MDPI, Basel, Switzerland. This article is an open access article distributed under the terms and conditions of the Creative Commons Attribution (CC BY) license (http://creativecommons.org/licenses/by/4.0/). 